\title{
Editorial
}

\section{Build back more equitably}

\author{
Kirsten Patrick MB BCh MSc
}

Cite as: CMAJ 2021 December 13;193:E1891-2. doi: 10.1503/cmaj.211987

See related article at www.cmaj.ca/lookup/doi/10.1503/cmaj.210904

a $\mathrm{n}$ this issue of CMAJ, Persaud and colleagues present guidance for policy-making as Canada begins to negotiate the long tail of the COVID-19 pandemic. $^{1}$ The pandemic emphasized the harms of social inequities in Canada, and the authors' recommendations call for the post-COVID-19 recovery to centre the principle of equity. Although one might imagine that all people are equally susceptible to a novel virus, it's become clear that some are at much higher risk of infection and death than others, owing to their circumstances. The pandemic has brought huge economic costs to individuals and governments. It may be tempting to think that restoring the economy to health should be governments' top priority before further spending on social safety nets, but failing to prioritize strengthening our fragile social systems in the short term would be a serious mistake.

At the start of 2021, hopes of a swift return to a "new normal" were dashed as the pandemic stretched out into third and fourth waves. Prolongation of the pandemic is explained partly by the fact that we've not merely experienced a global pandemic of a novel virus; we've experienced a syndemic, a coalescence of several major threats to health, including the important problem of growing social inequity. ${ }^{2}$ Many workers - some of whom were already at risk of severe illness from comorbidities - feared losing wages they needed to feed their families and pay their rent; they effectively had no choice but to go to work sick or return to work before they stopped being infectious, often with devastating consequences. Precariously housed people struggled to self-isolate. Although practically no one is going to emerge unaffected from the pandemic, relative privilege has allowed others to weather it without such great loss of income, shelter, safety and comfort.

Persaud and colleagues' new guidance echoes previous equity-focused recommendations for COVID-19 recovery ${ }^{3}$ in emphasizing the well-being of children and provision of resources for an adequate standard of living for all people through income protection. The authors have carefully graded the available scientific evidence for several interventions that could reasonably be implemented in the short term to support an equitable COVID-19 recovery. These include universal basic income, guaranteed sick leave and other income protections; publicly funded childcare; provision of housing to the marginally housed; legal interventions to protect individuals from intimate partner violence; and several mechanisms to provide equitable access to health care. ${ }^{1}$ Notably, no recommendations are provided for social care for older adults, which may surprise some readers, given the horror that played out in Canada's long-term care sector early in the pandemic.

Although the evidence for some recommendations is inconclusive, governments have no excuse for not implementing a few others right away. Doing so would protect people in Canada during future major crises - including increasingly frequent weather events related to climate change - that will almost certainly follow on the heels of the pandemic. One policy that would immediately lead to positive effects on the trajectory of the pandemic, and other health crises to come, is ensuring the provision of paid sick leave to all employees. It would limit the workplace outbreaks of communicable illness that have occurred during the pandemic. Paid sick leave was, however, conspicuously absent from the recent Speech from the Throne which, ironically, began with a call to "action on our collective health and well-being."

Persaud and colleagues chose specifically to recommend implementation of anti-racism policies as key to supporting population health in Canada as the country emerges from the pandemic. Despite being an ungraded recommendation, it is - appropriately - a strong one, given growing awareness, over the course of the pandemic, of the compounded harms experienced by racialized people in Canada and globally as a result of historic and ongoing colonialism and oppression. ${ }^{1}$ They note that decades of reports have outlined steps that can reasonably be taken to support reconciliation and anti-racism; the time to implement such actions is now.

To rekindle optimism and to try to address the economic effects of the pandemic, organizations and governments have long talked of "building back better." ${ }^{\text {-8 }}$ The main focus of most build-back-better initiatives is on restoring economies in the pre-pandemic image. However, it is the societal and structural problems that abetted the spread of SARS-CoV-2 - not the pandemic's economic effects - that have made COVID-19 such a devastating crisis. COVID-19 has taught us about the dangers of weakness in the fabric of society. Canadian policy-makers would do well to follow Persaud and colleagues' suggestion that postpandemic policy-making centre equity to ensure that all Canadians can benefit, and to protect against looming future threats. 


\section{References}

1. Persaud N, Woods H, Workentin A, et al.; MAP Task Force to Promote Health Equity during Pandemic Recovery. Recommendations for equitable COVID19 pandemic recovery in Canada. CMAJ 2021;193:E1878-88.

2. Horton R. Offline: COVID-19 is not a pandemic. Lancet 2020;396:874. Available: https://www.thelancet.com/journals/lancet/article/PIIS0 140 -6736(20)32000-6/fulltext (accessed 2021 Nov. 24).

3. Marmot M, Allen J, Goldblatt $P$, et al. Build back fairer: the COVID-19 Marmot review. London (UK): Institute of Health Equity; 2021. Available: https://www.instituteofhealthequity.org/resources-reports/build-back-fairer -the-covid-19-marmot-review (accessed 2021 Nov. 24).

4. Speech from the Throne. Building a resilient economy: a cleaner \& healthier future for our kids. Ottawa: Government of Canada; 2021 Nov. 23. Available: https://www.canada.ca/en/privy-council/campaigns/speech-throne/2021/ speech-from-the-throne.html (accessed 2021 Nov. 24).

5. Unifor's road map for a fair, inclusive and resilient economic recovery. Unifor.org. Available: https://buildbackbetter.unifor.org/ (accessed 2021 Nov. 24).

6. Building back better: a sustainable, resilient recovery after COVID-19. Paris (FR): Organisation for Economic Co-operation and Development; 2021. Available: https://www.oecd.org/coronavirus/policy-responses/building -back-better-a-sustainable-resilient-recovery-after-covid-19-52b869f5/ (accessed 2021 Nov. 24).
7. The build back better framework: President Biden's plan to rebuild the middle class. Washington (D.C.): The White House; 2021. Available: https://www.whitehouse.gov/build-back-better/\#: : text=The\%20 Build $\% 20$ Back\%20Better $\% 20$ framework $\% 20$ will\%20impose $\% 20$ a $\% 20$ $15 \% 25 \% 20$ minimum, avoid $\% 20$ paying $\% 20$ its $\% 20$ tax $\% 2$ bill (accessed 2021 Nov. 24).

8. Build back better: our plan for growth [policy paper]. London (UK): GOV UK; 2021 Mar. 3. Available: https://www.gov.uk/government/publications/ build-back-better-our-plan-for-growth (accessed 2021 Nov. 24).

Competing interests: See www.cmaj.ca/site/misc/cmaj_staff.xhtml.

Affiliations: Interim editor-in-chief, CMAJ

Content licence: This is an Open Access article distributed in accordance with the terms of the Creative Commons Attribution (CC BY-NC-ND 4.0) licence, which permits use, distribution and reproduction in any medium, provided that the original publication is properly cited, the use is noncommercial (i.e., research or educational use), and no modifications or adaptations are made. See: https://creativecommons.org/licenses/ by-nc-nd/4.0/

Correspondence to: CMAJ editor, editorial@cmaj.ca 